\title{
Preparasi Pollen Tanaman Tembakau (Nicotiana tabacum L.) Untuk Penyinaran Sinar Gamma
}

\author{
Faishal Aliwardana dan Nurul Jadid \\ Departemen Biologi, Fakultas Ilmu Alam, Institut Teknologi Sepuluh Nopember (ITS) \\ e-mail:nuruljadid@bio.its.ac.id
}

\begin{abstract}
Abstrak-Selama ini pemuliaan budidaya tembakau varietas somporis masih dilakukan secara konvensional. Pemuliaan secara konvensional sering mengalami kendala seperti masa produksi yang lebih lama dan hasil yang diperoleh tidak seragam. Oleh karenanya diperlukan alternatif teknik pemuliaan budidaya tembakau yang lebih cepat dan efisien. Salah satu teknik yang dapat dikembangkan adalah induksi ginogenesis untuk membentuk tanaman haploid menggunakan pollen yang diiradiasi sinar gamma. Tahap preparasi pollen sebelum dilakukan penyinaran sinar gamma sangat penting dilakukan. Proses pembibitan tanaman tembakau mulai dari benih, fase vegetatif hingga fase generatif dilakukan sesuai dengan panduan budidaya tanaman tembakau. Bunga yang digunakan untuk pemanenan pollen adalah bunga yang memiliki ciri panjang bunga $\pm 5-5,5 \mathrm{~cm}$, ujung mahkota bunga sedikit membuka dan berwarna hijau kekuningan. Pollen yang didapat disimpan pada suhu $4^{\circ} \mathrm{C}$ selama 3 hari untuk menunggu tanaman donor berbunga. Hasil penelitian menunjukan tanaman tembakau varietas somporis menghasilkan rata-rata $5,5 \mathrm{mg}$ pollen per bunga. Setelah dipolinasi pada tanaman donor, pollen yang telah disimpan selama 3 hari pada suhu $4^{\circ} \mathrm{C}$ memiliki viabilitas yang tinggi. Hal ini dapat dilihat dari persentase pembentukan polongnya yang mencapai $100 \%$.
\end{abstract}

Kata Kunci-Ginogenesis, Pembibitan, Pollen, Sinar Gamma, Tembakau var. Somporis.

\section{PENDAHULUAN}

$\mathrm{K}_{\mathrm{r}}^{\mathrm{o}}$ OMODITI tembakau mempunyai arti yang cukup penting, tidak hanya sebagai sumber pendapatan bagi para petani, tetapi juga bagi negara yaitu pada sektor cukai pajak. Tembakau digunakan salah satunya sebagai bahan utama dalam industri rokok [1]. Selain itu tanaman tembakau juga sering dimanfaatkan sebagai biopestisida, sebagai pelengkap makan sirih dalam upacara adat dan bijinya dapat digunakan sebagai bahan baku minyak cat [2].

Kementerian Perindustrian (Kemenperin) mencatat, kebutuhan akan tanaman tembakau dari tahun ke tahun terus meningkat. Berdasarkan catatan Kemenperin, pertumbuhan produksi rokok naik pada kisaran $5 \%$ hingga $7,4 \%$ per tahun. Namun hal ini tidak diimbangi dengan faktor produksi tembakau. Saat ini, luas lahan kebun tembakau hanya 192.525 hektare (ha) dengan produksi sebesar 163.187 ton per tahun. Padahal beberapa tahun lalu, kebun tembakau di Indonesia bisa seluas 260.000 ha. Sehingga Indonesia masih mengimpor $40 \%$ dari total kebutuhan tembakau domestik [3].

Dalam rangka memenuhi kebutuhan produksi tembakau tersebut, dibutuhkan varietas unggul yang mampu meningkatkan produktivitas tanaman tembakau. Varietas yang sedang banyak dikembangkan saat ini adalah varietas Somporis. Keunggulan dari varietas Somporis ini adalah memiliki ukuran tanaman yang lebih tinggi dibandingkan varietas yang lain, serta tahan terhadap serangan virus TMV dan TLC [4]. Namun keanekaragaman benih sangat tinggi karena umumnya petani membibitkan tanaman ini tanpa melalui proses pembenihan yang ketat [5].

Selama ini pemuliaan budidaya tembakau masih dilakukan secara konvensional dengan cara penyerbukan sendiri (self inbreeding) yang diikuti dengan seleksi. Pemuliaan tembakau secara konvensional sering mengalami kendala-kendala seperti masa produksi yang lebih lama dan hasil yang diperoleh tidak seragam [6]. Di samping itu, teknik budidaya secara konvensional ini membutuhkan lahan pengembangan yang relatif luas. Hal ini dikarenakan teknik pemuliaan secara konvensional mengharuskan proses seleksi berkelanjutan minimal hingga keturunan atau generasi ke-8 dan waktu minimal 7 tahun [7]. Oleh karena itu diperlukan alternatif teknik pemuliaan budidaya tembakau yang lebih cepat dan efisien untuk mengurangi lama waktu dan ketidakstabilan genetik. Salah satu teknik yang dapat dikembangkan untuk mengatasi kendala-kendala tersebut adalah teknik double haploid menggunakan pollen yang diiradiasi sinar gamma untuk membentuk tanaman galur murni atau homozigot. Sebelum perlakuan iradiasi sinar gamma, perlu dilakukan preparasi pollen mulai dari pembenihan hingga tanaman memasuki fase generatif (berbunga). Setelah memasuki fase generatif pollen dapat dipanen dan dikumpulkan. Preparasi pollen sangat penting untuk mengetahui kuantitas pollen yang dihasilkan dan untuk menjaga pollen tetap viabel, karena pollen memiliki sifat yang sangat rentan terhadap kondisi eksternal yang kurang sesuai.

Penelitian ini bertujuan untuk memperoleh informasi perlakuan preparasi pollen tembakau yang baik untuk mendapatkan pollen yang berkualitas sebelum dilakukan penyinaran sinar gamma. Sehingga harapannya akan dapat berguna untuk penelitian selanjutnya yaitu induksi pembentukan tanaman tembakau haploid.

\section{METODOLOGI PENELITIAN}

\section{A. Waktu dan Tempat}

Penelitian ini dilakukan selama 6 bulan (Februari - Juli 2017) di Greenhouse Urban Farming ITS Surabaya yang meliputi persiapan media pembibitan, perawatan bibit semai, persiapan media tanam, pemindahan bibit semai ke media tanam, perawatan tanaman, dan pemanenan bunga. Selanjutnya sampel pollen dipreparasi dan disimpan di Laboratorium Biosains dan Teknologi Tumbuhan untuk menunggu tanaman donor berbunga. Benih tanaman 
tembakau varietas Somporis didapat dari PT Sadhana Purwosari.

\section{B. Alat dan Bahan}

Alat yang digunakan dalam penelitian ini adalah nampan, sprayer, gunting, penggaris, kamera, polybag, sekrup, ziplock, cawan Petri, plastik wrap, saringan, botol plakon, lemari pendingin, kuas, sedotan, tali, neraca analitik.

Bahan yang digunakan untuk penelitian ini adalah tanah, pupuk kompos, $\mathrm{NPK}, \mathrm{KNO}_{3}$, cocopeat, fungisida, pestisida, herbisida, pasir, aquades, air.

\section{Cara Kerja}

Penelitian ini terdiri atas beberapa persiapan media pembibitan, perawatan bibit semai, persiapan media tanam, pemindahan bibit semai ke media tanam, perawatan tanaman, pemanenan bunga, pemisahan anter dari bunga, pemanenan dan penyimpanan pollen, serta uji viabilitas pollen.

\section{1) Persiapan Media Pembibitan}

Benih tanaman tembakau disemai dalam nampan berlubang dengan komposisi media tanam tanah, pupuk kompos dan cocopeat dengan perbandingan 2:1:1. Selain itu diberikan juga pupuk $\mathrm{NPK}, \mathrm{KNO}_{3}$ dan fungisida. Benih sebelumnya direndam selama sehari semalam pada aquades. Setelah itu benih disebar rata pada permukaan media tanam secara vertikal dari bagian ujung atas nampan hingga bagian ujung bawah nampan dengan terlebih dahulu benih dicampur secara merata dengan butiran pasir halus. Bagian bawah media diberi wadah yang berisi sedikit genangan air untuk menjaga kelembapan media tanam

\section{2) Perawatan Bibit Semai}

Bibit semai disiram dua kali sehari pada pagi dan sore hari dengan sprayer. Wadah bagian bawah media harus selalu diisi dengan sedikit genangan air agar tingkat kelembapan tanah terjaga. Bibit semai disiram dengan pupuk NPK setiap tiga hari sekali. Setelah tumbuh dua daun dan ukurannya menutupi media, daun sedikit dipangkas (kliping).

\section{3) Persiapan Media Tanam}

Tanaman tembakau ditanam di dalam greenhouse menggunakan polybag dengan komposisi media tanam tanah, pupuk kompos berupa arang sekam dan cocopeat dengan perbandingan 2:1:1. Selain itu diberikan juga pupuk NPK dan $\mathrm{KNO}_{3}$ pada media tanam sebelum media ditanami bibit tembakau.

\section{4) Pemindahan Bibit Semai ke Media Tanam}

Sebelum bibit dipindah, terlebih dahulu media disiram hingga benar-benar basah. Bibit yang dipilih untuk dipindah dan ditanam pada polybag adalah bibit yang memiliki ukuran seragam dan juga memiliki stem yang besar dan kokoh, agar saat dipindah ke media polybag bibit tidak mudah layu dan mati.

\section{5) Perawatan Tanaman}

Perawatan tanaman dilakukan dengan pemberian pupuk pertama menggunakan pupuk NPK, setelah berumur 21 hari dilakukan pemupukan dengan $\mathrm{KNO}_{3}$. Penyiraman dilakukan setiap hari saat awal, dan setiap 3 hari setelah tanaman benarbenar hidup. Pemberian pestisida dan fungisida dilakukan sebulan sekali.

\section{6) Pemanenan Bunga}

Setelah berumur \pm 60 hst (hari setelah tanam) tanaman tembakau varietas somporis memasuki fase generatif dan dapat mengasilkan bunga. Bunga yang digunakan untuk pemanenan pollen adalah bunga yang memiliki ciri panjang bunga $\pm 5-5,5 \mathrm{~cm}$, ujung mahkota bunga sedikit membuka dan berwarna hijau kekuningan. Bunga tersebut dikumpulkan dalam ziplock dan disimpan didalam laboratorium.

\section{7) Pemisahan Anter dari Bunga}

Kuncup bunga tanaman tembakau yang telah dikumpulkan disobek pada bagian ujungnya dan dibuka secara perlahan. Terdapat 5 anter didalam kuncup bunga tembakau dan usahakan ke lima anter tersebut dalam kondisi belum pecah saat pemisahan dari bunga. Anter dipisahkan dan dimasukan ke dalam cawan petri yang telah diberi alas berupa kertas. Anter tersebut kemudian disimpan pada suhu pendingin ruangan $\left( \pm 19^{\circ} \mathrm{C}\right)$.

\section{8) Pemanenan dan Penyimpanan Pollen}

Setelah anter pecah maka butiran pollen akan keluar. Butiran pollen dipisahkan dari anter yang mengering dengan alat bantu saringan. Pollen yang telah terpisah dari anter kemudian dimasukan dalam botol plakon dan ditutup dengan rapat. Botol plakon tersebut kemudian disimpan pada lemari pendingin dengan suhu $\pm 4{ }^{\circ} \mathrm{C}$ untuk menjaga pollen tetap viabel sambil menunggu tanaman donor berbunga.

\section{9) Uji Viabilitas Pollen}

Setelah tanaman tembakau donor mulai berbunga, bunga tanaman donor tersebut diberi perlakuan emaskulasi (pengebirian). Perlakuan emaskulasi ini dilakukan sebelum bunga mekar sempurna dan sebelum anter pecah. Setelah diemaskulasi, putik tanaman tersebut dipolinasi menggunakan pollen yang telah disimpan dan dikumpulkan sebelumnya. Polinasi pollen ke putik menggunakan alat bantu kuas. Setelah dipolinasi, putik ditutup dengan sedotan yang telah disumbat pada bagian atasnya dan ditandai dengan tali kecil. Jumlah tanaman donor yang dipolinasi adalah sejumlah tiga tanaman dengan masing-masing tanaman lima bunga yang dipolinasi.

\section{HASIL DAN PEMBAHASAN}

\section{A. Pemanenan Bunga dan Total Pollen yang Dihasilkan}

Bunga tanaman tembakau varietas somporis yang digunakan untuk pemanenan pollen adalah yang memiliki ciri panjang bunga $\pm 5-5,5 \mathrm{~cm}$, ujung mahkota bunga sedikit membuka dan berwarna hijau kekuningan (gambar 1). Bunga ini dipilih karena anter masih dalam keadaan utuh dan belum pecah, sehingga kuantitas pollen yang dapat dipanen jumlahnya optimal. Jika anter telah pecah sebelum dipisahkan dari bunga akan menyebabkan banyak pollen yang jatuh sebelum dapat dikumpulkan. Setelah dipanen dan dikumpulkan, pollen dari stage bunga ini menghasilkan cairan yang lengket dan basah yang menandakan pollen dalam keadaan matang dan siap untuk berkecambah. Hal ini sesuai dengan [8] yang mengatakan bahwa pollen tembakau menghasilkan pollenkit yang basah, lengket dan berwarna. Pollenkit ini mengandung lemak, protein, karbohidrat dan senyawa fenolik serta enzim. Peningkatan kelekatan butiran tepung sari ini mengindikasikan bahwa tepung sari tersebut telah siap untuk berkecambah. [9] juga mengatakan bahwa semakin tua umur bunga akan semakin tinggi frekuensi 
mikrospora pada tahap lebih lanjut (late uninucleat dan early binucleat). Untuk meningkatkan persentase perkecambahan, mikrospora harus berada pada tahap perkembangan yang sesuai, yakni mulai dari tahap uninukleat tengah "miduninucleate" hingga tahap binukleat awal "early-binucleate". Populasi mikrospora uninukleat yang lebih besar sangat berhubungan dengan ukuran bunga. Tahapan perkembangan mikrospora di dalam anter sangat ditentukan oleh ukuran bunga dan antera, sehingga penggunaan ciri morfologi bunga atau ukuran kuncup adalah cara yang tepat dalam menentukan tahap perkembangan mikrospora.

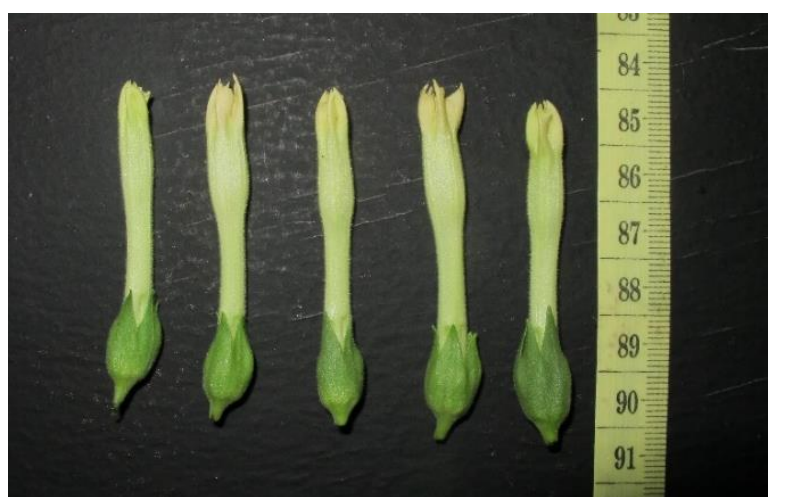

Gambar 1. Bunga tembakau var. somporis yang digunakan untuk pemanenan pollen

Berdasarkan penelitian yang telah dilakukan didapatkan total pollen yang dihasilkan adalah sebanyak $0,11 \mathrm{~g}$ dari 20 bunga. Jadi rata-rata total pollen yang dihasilkan bunga tembakau varietas somporis adalah sebanyak $\pm 5,5 \mathrm{mg}$ pollen per bunga.

\section{B. Penyimpanan Pollen}

Pollen yang telah didapatkan dimasukan dalam wadah botol dan disimpan pada lemari pendingin dengan suhu $4{ }^{\circ} \mathrm{C}$. Hal ini bertujuan agar pollen tetap dalam keadaan viabel pada jangka waktu yang lama. Hal ini sesuai dengan pendapat [10] yang mengatakan bahwa penyimpanan pada suhu rendah metabolisme sel menurun akibat kadar oksigen berkurang sehingga menyebabkan respirasi sel dan aktivasi enzim menurun. Hal inilah yang menyebabkan pollen yang disimpan pada suhu rendah memiliki daya simpan yang lebih lama. Pada suhu ruang dan suhu tinggi viabilitas pollen akan cepat menurun. Hal ini sesuai dengan penelitian [11], pada tanaman Nicotiana alata yang diberi perlakuan suhu $20{ }^{\circ} \mathrm{C}$ viabilitasnya mampu bertahan selama \pm 400 jam. Pada suhu $30{ }^{\circ} \mathrm{C}$ viabilitasnya menurun drastis menjadi \pm 80 jam. Menurunnya viabilitas pollen menurut [12] adalah karena pollen yang diberi cekaman suhu tinggi pertumbuhan tabung pollennya terhambat, yang menyebabkan pollen tube (tabung pollen) hanya mencapai stilus dan tidak dapat mencapai ovule, sehingga tidak terjadi fertilisasi. Pemberian cekaman suhu $80^{\circ} \mathrm{C}$ pada pollen mengakibatkan denaturasi protein dan kematian sel. Berdasarkan penelitian tersebut didapatkan bahwa pollen tidak dapat disimpan dalam jangka waktu lama pada suhu tinggi dan suhu udara normal, sehingga diperlukan pemberian perlakuan suhu rendah untuk menyimpan pollen agar viabilitasnya tetap terjaga.

\section{Uji Viabilitas Pollen}

Tanaman donor berbunga setelah pollen yang dipreparasi disimpan selama 3 hari. Tanaman donor yang dipilih untuk dipolinasi adalah tanaman dengan bunga yang telah matang dan anter yang belum pecah. Kematangan bunga pada tanaman tembakau donor ditandai dengan warna ujung kuncup mahkota bunga berwarna hijau kemerahan dan bagian pangkal bunga berwarna hijau cerah, selain itu kematangan bunga ditandai dengan pada bagian putik terdapat cairan kental yang berguna sebagai media pelekatan pollen. Setelah bunga didapatkan, mahkota bunga disobek secara perlahan dan dilakukan perlakuan emaskulasi (pengebirian). Perlakuan emaskulasi bertujuan untuk menghilangkan anter dari benang sari agar pollen dari tanaman donor tersebut tidak mengkontaminasi putik, sehingga polinasi terjadi antara putik tanaman donor dengan pollen yang telah di preparasi dan disimpan sebelumnya. Polinasi pollen ke putik mengggunakan alat bantu kuas. Setelah dipolinasi pollen ditutup dengan sedotan yang telah disumbat pada bagian atasnya. Penutupan ini bertujuan untuk melindungi putik yang telah dipolinasi dari faktor pengganggu biotik dan abiotik dari lingkungan eksternal, seperti air hujan, debu, hama dan lain sebagainya. Kemudian putik yang telah dipolinasi tersebut ditandai dengan tali kecil.

Hasil penelitian menunjukan viabilitas dan kualitas pollen yang telah preparasi dan disimpan selama 3 hari pada suhu 4 ${ }^{\circ} \mathrm{C}$ cukup tinggi. Hal ini ditunjukan dengan dari 15 bunga pada tiga tanaman donor yang dipolinasi menggunakan pollen yang telah di preparasi, seluruhnya berhasil menghasilkan polong yang normal (gambar 2). Hal ini mengindikasikan bahwa perlakuan preparasi dan penyimpanan polen telah dilakukan dengan benar dan tidak mempengaruhi kualitas dan viabilitas pollen. Keberhasilan pembentukan polong mengindikasikan bahwa pollen dapat berkecambah dengan baik saat berada pada stigma. Selain itu perkembangan dan pemanjangan pollen tube tidak terhambat sehingga pollen tube dapat mencapai ovula dan terjadi proses fertilisasi [12].

Menurut [13] Polong (buah) tanaman tembakau berbentuk seperti telur ayam dengan panjang antara 1,5-2 cm. Saat muda buah berwarna hijau dan saat matang berubah warna menjadi cokelat. Ovarium terletak diatas dasar bunga dan mempunyai dua ruang yang membesar. Pada umumnya setiap buah menghasilkan 2000 - 3000 biji, dengan berat 1000 biji kurang lebih $0,05-0,09$ g. Setiap tanaman menghasilkan rata-rata 6 - $7 \mathrm{~g}$ biji.

Proses preparasi pollen dilakukan untuk mengetahui kuantitas pollen yang dapat dihasilkan dari bunga tanaman tembakau varietas somporis. Preparasi pollen ini juga dilakukan untuk mengetahui pengaruh perlakuan pemanenan dan penyimpanan pollen terhadap kualitas dan viabilitas pollen tersebut. Hasil proses preparasi pollen ini akan digunakan untuk penelitian selanjutnya yaitu induksi ginogenesis menggunakan pollen yang diberi penyinaran sinar gamma untuk membentuk tanaman tembakau haploid. Berdasarkan penelitian [14] pada tanaman tembakau pemberian dosis iradiasi sinar gamma 600 gy pada pollen dapat menjamin terbentuknya tanaman haploid.

\section{KESIMPULAN}

Hasil penelitian menunjukkan bahwa pemberian perlakuan preparasi pollen mulai dari pembibitan hingga pemanenan dan penyimpanan pollen telah dilakukan dengan baik. Tanaman tembakau varietas somporis menghasilkan pollen rata-rata $5,5 \mathrm{mg}$ pollen/bunga. Pollen yang dipreparasi memiliki kualitas dan viabilitas yang tinggi yang ditunjukan 
dengan persentase keberhasilan pembentukan polongnya yang mencapai $100 \%$.
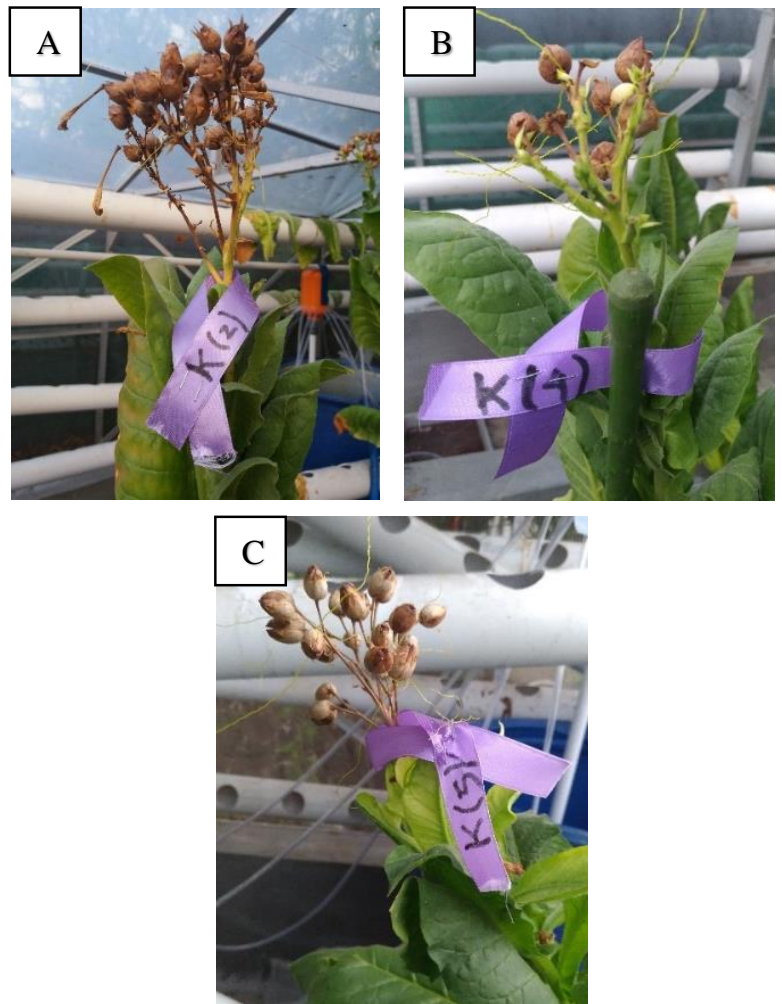

Gambar 2 A: Polong yang dihasilkan setelah dipolinasi. A: tanaman donor 1; B: tanaman donor 2; C: tanaman donor 3

\section{DAFTAR PUSTAKA}

C. Hanum, Teknik Budidaya Tanaman Jilid 3. Jakarta: Departemen
Pendidikan Nasional, 2008.

[2] Suwarso, "Pewarisan Ketahanan Terhadap Penyakit Lanas Pada Tembakau Madura Prancak-95," Zuriat, vol. 20, no. 1, 2009.

[3] Kemenperin, "Artikel Produksi Tembakau Siap Bangkit," kemenperin.go.id, 2016. [Online]. Available: kemenperin.go.id/artikel/13782/.

[4] Sadhana, Buku Kunci Identifikasi Tanaman Tembakau. Purwosari: SAC, 2016

[5] Ballitas, "Booklet Tembakau Virginia Di Jawa Timur," Surabaya, 1991

[6] P. Daisy, H. Sriyanti, and W. Ari, Teknik Kultur Jaringan: Pengenalan dan Petunjuk Perbanyakan Tanaman Secara Vegetatif-Modern. Yogyakarta: Kanisius, 1994.

[7] dan I Suwarso, A. Herwati, A. Rachman, Heterosis Pada Persilangan Antara Tembakau Madura dan Oriental. Malang: Balittas, 1997.

[8] M. Griffin, A. R., and Sedgley, Sexual Reproduction of Tree Crop San Diego: Academic Press, inc, 1989.

[9] F. Volcov, R. A., Irina, Panchuk, I., Schoffl, "Small Heat Shock Proteins Are Differentially Regulated During Pollen Development and Following Heat Stress in Tobacco," Plant Mol. Biol., vol. 57, pp. 487-502, 2005.

[10] E. Alwi, M., Yuniati, "Efek Radiasi Sinar Gamma Terhadap Perkecambahan Serbuk Sari dan Pembuahan Cabai Besar," Biocelebes, vol. 3, no. 2, 2009.

[11] J. Hoekstra, F.A. and Bruinsma, "Viability of Compositae pollen: germination in vitro and influences of climatic conditions during dehiscence," Zeitschrift fur Planzenphysiologie, vol. 76, pp. 3643, 1975.

[12] M. Shivanna, K.R., Linskens, H. F and Cresti, "Responses of tobacco pollen to high humidity and heat stress: viability and germinability in vitro and in vivo," Sex. Plant Reprod., vol. 4, pp. 104-109, 1991.

[13] S. Basuki, S., Suwarso, Herwati, A., Yulaikah, Biologi dan Morfologi Tembakau Madura. Malang: BALITTAS, 2000.

[14] Suharsono, "Effet Du Gene Mitochondrial Atp9 Non- Edite Sur La Fertilite, Chez Des Plantes Transgeniques De Nicotiana tabacum," These Dr. Univ. Bordeaux II, 1993. 